\title{
Working Capital Structure and Financing Pattern of Selected JSE-Listed Firms
}

\author{
Farai Kwenda \\ Merle Holden
}

Respectively Lecturer and Research Associate in the School of Accounting, Economics and Finance, University of KwaZulu-Natal

Doi:10.5901/mjss.2013.v4n13p531

\begin{abstract}
The paper analyses the working capital structure and financing patterns of companies listed on the JSE Securities Exchange. Data was collected from 92 companies in eight economic sectors for the period 2001-2010 and analysed using descriptive statistics and trend analysis. Working capital management has grown in significance from being a survival issue to a strategic and competitive tool. The study reveals that the listed companies heavily depend on trade credit as the source of short term finance and trade receivables and inventory are their main working capital investment. The results show that firms in different economic sectors use different approaches to manage their current assets and change working capital policies in line the state of the economy.
\end{abstract}

Keywords: working capital financing, investment, pattern, conservative, aggressive

\section{Introduction}

The success or failure of any business enterprise depends largely on its ability to make sound financial management decisions. These decisions can be discussed under three categories; capital budgeting, capital structure and working capital management. Working capital management decisions involve decisions about the amount of current assets to maintain and the financing of those current assets. The financing and composition of current assets determines the liquidity position of the firm and is a major challenge for finance managers because of the dynamic and highly volatile nature of short-term markets, the level of competition, inflation, cost of capital and pressure to deliver maximum shareholder value (Lamberson, 1995; Salawu, 2007). Survival and sustainability while attempting to grow in today's highly competitive business environment and changeable financial markets makes it imperative for businesses to adjust their strategies and adopt sound financial policies, in particular the management and financing of working capital.

The subject of working capital management has gained importance because it has become contemporary financial management paradox. On one hand there is growing evidence that firms are over investing in working capital. For example, Ernst. and Young (2010) estimated that over US $\$ 450$ billion was being held in working capital unnecessarily by the biggest 1000 American companies by sales while the top 1000 European firms held $€ 475$ billion. In its 2009 Working Capital Survey of the top 1000 US companies, REL (2009) found that firms were unnecessarily holding approximately US $\$ 778$ billion tied up in working capital. On the other hand, firms are searching for cheaper sources of funds, lamenting high borrowing costs and the inaccessibility of credit markets. The financing of working capital has become a very significant area of financial management as firms can no longer easily use borrowing as an escape route out of financial difficulties due to stringent credit policies being pursued lending institutions (Chiou, Cheng, \& Wu, 2006; Zapalska, Clark, \& Shao, 2004). In addition, raising funds in capital markets has shown to be increasingly difficult to access and costly (Salawu, 2007). In South Africa, the implementation of the National Credit Act (NCA) in 2007 has tightened access to credit which makes the financing of working capital an interesting subject.

The recent the global economic crisis rocked financial markets negatively impacting on the firms' ability to access funds as banks applied more strict measures were applied to borrowers. Good working capital management acts as a hedge against tightening credit and reduced access to external capital. Siddiquee and Khan (2009) content that during economic downturns, companies with good working capital management practices can make counter-cyclical moves to build a competitive advantage using internally generated funds to finance their research programmes and expansions. Thus such companies are better able to withstand economic downturns with the possibility of emerging in a stronger position. 
Research into the area of working capital financing in South Africa, an important emerging market economy in Africa, is limited. In an attempt to add to the growing literature in other emerging economies, this paper examines the working capital structure and financing practices of firms listed on the JSE operating in one of the most well-developed and advanced capital market and the banking system in the world which compares favourably to the financial systems of more developed economies (Skerritt, 2009). The main objectives of the paper are to determine the financing of working capital for selected JSE-listed firms in eight economic sectors and establish the pattern of data over a ten-year period. One of the key findings of the study is that trade credit is the most dominant short-term financing instrument among listed firms in South Africa. Trade credit finances approximately half of the current assets held by JSE-listed sample firms. Sample firms particularly in the retail sector firms mainly hold working capital investment in the form of inventory and trade receivables. Trend analysis suggests that firms tend to align the working capital investments to prevailing economic conditions.

The rest of the paper is organised as follows; Section 2 reviews the literature on the management and financing of working capital. Section 3 presents the description of data sources and the sample used. These data are presented and analysed in Section 4 and the conclusions drawn are presented in last section.

\section{Literature Review}

In addition to capital budgeting and capital structure, working capital management is one of the three major financial management decisions facing a financial manager. Working capital management can be defined as the administration of current assets and current liabilities ensuring that the firm has sufficient resources to continue its operations and avoid costly interruptions (Firer, Ross, Westerfield, \& Jordan, 2012). Current assets include cash and marketable securities, trade receivable, prepaid expenses and inventory/stock (raw materials + work-in-progress + finished goods) and current liabilities include accounts payable, short term bank loans, other payables and accruals becoming due within a year.

Gross working capital is defined as a company's investment in current assets whereas net working capital refers to the difference between current assets and current (Gitman et al., 2010; Sathyamoorthi \& Wally-Dima, 2008). Working capital has also been defined as short term assets and liabilities collectively (Brealey, Myers, \& Allen, 2008). Padachi (2006) defines working capital as trading capital that is not retained in the business in a particular form for longer than a year. According to Chiou et al. (2006) working capital represents sources and uses of short-term capital. This study uses the concept of gross working capital defined as investments in current assets that are considered to be the lifeblood and the controlling nerve centre of the business. Gross working capital therefore represents the portion of investment that circulates and changes form and substance during the ordinary course of business operations.

Working capital policy refers to the decisions regarding the target levels for each category of current assets and the financing of those current assets (Sathyamoorthi \& Wally-Dima, 2008). There are three working capital policies; aggressive (restrictive), conservative (flexible) and the compromise (moderate) approach. Under an aggressive policy, the firm maintains a low ratio of current assets to sales, uses a high proportion of short term debt relative to long term funds. An aggressive working capital policy results in current liabilities exceeding current assets, (negative net working capital) implying that short term funds are used to finance part of non-current assets and the negative contribution of long term funds (Van Horne, 2002). Under the conservative policy, the firm maintains a relatively large investment in current assets to sales which are financed by relatively greater long term funds and less short term debt. A conservative working capital policy results in current assets exceeding current liabilities (positive net working capital), implying that long term funds are used to finance part of current assets. The compromise policy falls between the aggressive and the conservative policies. Under this approach, the firm takes moderate risk in managing its working capital and attempts to match the maturity structure of assets and liabilities.

The operations of most firms are subject to seasonal fluctuations and current assets levels rarely fall to zero, consequently most firms have permanent working capital and temporary working capital (Sathyamoorthi \& Wally-Dima, 2008). Permanent working capital is the amount needed to maintain current assets at the minimum level and this amount is usually met from long term funds (long term debt and equity). Temporary working capital is any amount over and above the permanent working capital and is largely due to seasonal changes in the level of business activity. Under each working capital policy seasonal variations are financed differently (Firer et al., 2012). A firm using the aggressive policy relies heavily on short-term debt to fund its temporary/seasonal requirements and a firm using the conservative policy uses its own cash and marketable securities to fund seasonal requirements. Under the compromise policy the firm borrows to cover peak financing needs but maintains a cash reserve in the form of marketable securities during periods of low business activity. As current assets build up the firm draws down this reserve before doing any short term 
borrowing.

Working capital finance can be classified as long-term finance and short-term finance. There are four main sources of long-term funds, which can be used to fund working capital investments, namely equity, long term debt, offbalance sheet financing and asset-based financing. Short-term working capital finance can be classified as spontaneously generated sources (trade credit, provisions and accruals) and non-spontaneously generated sources (unsecured and secured short-term borrowings and financing instruments). Spontaneous sources are "cost free" and arise from the normal course of business (Gitman et al., 2010). As sales increase, trade payables and other payables increase in response to the increased purchases necessary to produce at higher levels. Secured short-term borrowings are usually made up of short term bank loans, overdraft, and loans. Unsecured financing (also known as financial statements lending) is short-term financing obtained from the money market without pledging any specific assets as collateral. Negotiable certificates of deposit, commercial paper, banker's acceptances are the main non-government money market instruments used in unsecured financing.

The Pecking Order Theory advanced by Myers (1984) has been greatly used to explain managers' financing preferences. The theory postulates that managers prefer internal financing to external financing and debt to external equity. This hypothesis states that businesses adhere to a hierarchy of financing sources and prefer internal financing (retained earnings) when available; and if external financing is required, debt is preferred over equity. Trade credit and bank credit are the major sources of working capital finance for most firms.

\section{Methodology and Data Sources}

The components of gross working capital are now analysed using trend analysis in order to ascertain whether there were any structural changes over the period of study. The mean of each year is computed and then put together in order to establish the trend. The study also attempts to assess the liquidity of the sample in the eight sectors, using a comprehensive test, based on liquidity ranks (LR). This is calculated first by assigning an individual ranking to each of the four main components of current assets and then summed over the individual scores to arrive at an ultimate rank. The same approach was used in establishing the sectoral liquidity rankings.

The empirical study is based on a sample of 92 firms listed on the JSE in the following economic sectors; chemical and oil, consumer goods, retail, industrials, construction, mining, technology and leisure as classified by the McGregor BFA Library, the source of the study data. Sample data was collected from the financial statements for the accounting period 2001 to 2010. Sample selection was guided by data availability; firms with missing data were excluded while sectors with less than four firms were also excluded.

\section{Results and Analysis}

\subsection{Sources of working capital finance}

Finance managers continuously face the challenge of deciding the size and means of financing the current assets. Table 1 shows the trends and composition of current liabilities over the ten year period. The results in Table 1 show that trade credit to current liabilities (TCCL); fluctuates between $67 \%$ and $72 \%$ without following a well-defined trend. The average TCCL (68\%) is more than three and six times higher than the contributions of short term financial debt to current liabilities (STDCL) and accruals to current liabilities (ACCL) respectively. In relating the Pecking Order Theory to working capital financing, it seems that trade credit is these firms' first choice of external finance, probably because it is cost free and is available as part of the trade terms. Reliance on trade credit as a source of funds is typical for emerging markets (Maksimovic \& Demirgüç-Kunt, 2001) and could explain the fact that suppliers have significant cost advantages over financial institutions when it comes to providing credit to their customers. Three sources of such cost advantages lie in the informational advantage as a result of the continued trading relationship, control over the actions of the buyer and the ability to seize the goods if the buyer defaults (Bhattacharya, 2009; Petersen \& Rajan, 1997). The sample comprises very large firms; therefore it is possible that the heavy reliance on trade credit could be a result of competition amongst suppliers competing for business of listed firms, which works to the advantage of these listed firms.

STDCL did not follow a particular pattern in the first five years but was generally on an upward trend for the remainder of the study period. The average STDCL was $20 \%$ and the minimum and maximum contributions were reported respectively as follows; $16 \%$ in 2005 and $21 \%$ in 2009. These data suggests that these firms relied less on short term when interest rates are low and borrowed more when interest rates were high. Appendix 1 shows that lending rates 
high in 2009 and low in 2005. This finding could suggest in times of a credit crunch, access to finance supersedes the costs of finance and as a result in firms borrow even at extremely high interest rates in order keep their operations running.

Over the ten year period, the contribution of accruals to total short term finance went on upward trend, from $11.6 \%$ in 2001 , peaking at $15.10 \%$ in 2005 and then trended downwards during the last five years of the period under review.

Table 1: Composition of Current Liabilities

\begin{tabular}{|l|l|l|l|}
\hline Year & TCCL & STDCL & ACCL \\
\hline $\mathbf{2 0 0 1}$ & 0.6820 & 0.2019 & 0.1161 \\
\hline $\mathbf{2 0 0 2}$ & 0.6961 & 0.1850 & 0.1189 \\
\hline $\mathbf{2 0 0 3}$ & 0.6778 & 0.1960 & 0.1262 \\
\hline $\mathbf{2 0 0 4}$ & 0.6823 & 0.1767 & 0.1410 \\
\hline $\mathbf{2 0 0 5}$ & 0.6857 & 0.1633 & 0.1510 \\
\hline $\mathbf{2 0 0 6}$ & 0.6728 & 0.1761 & 0.1510 \\
\hline $\mathbf{2 0 0 7}$ & 0.6728 & 0.1905 & 0.1376 \\
\hline $\mathbf{2 0 0 8}$ & 0.6699 & 0.1996 & 0.1305 \\
\hline $\mathbf{2 0 0 9}$ & 0.6976 & 0.2052 & 0.0981 \\
\hline $\mathbf{2 0 1 0}$ & 0.7212 & 0.1836 & 0.0952 \\
\hline overall & $\mathbf{0 . 6 8 2 0}$ & $\mathbf{0 . 2 0 1 9}$ & $\mathbf{0 . 1 1 6 1}$ \\
\hline
\end{tabular}

Source: Own calculations using a balanced panel over the period 2001 to 2010. Data obtained from the McGregor BFA library.

Table 2 shows the composition of short-term finance in the eight sectors in the sample. The retail and the technology sector heavily depend on trade credit as a source of short term finance. Over $80 \%$ of short-term finance comes from trade credit. The results of the retail sector are consistent with expectations about this sector because this sector uses trade credit as a major source of finance. Retailers can buy and sell merchandise before paying for it, a practice that cannot be easily done by other sectors. As a result, some companies in the retail sector have reported negative cash conversion cycles. The extensive use of trade credit as a source of funds probably also explains its less dependence on short-term financial debt. Short-term financial debt contributes only $7 \%$ to total short term finance for the retail sector. Nearly half of the short-term finance of the mining and leisure and recreation sectors comes from trade credit. Coincidentally, the mining and leisure and recreation sectors have the highest uses of short term financial debt and accruals as sources of short term finance. The technology sector is the lowest user of accruals as a source of finance (only 6\%).

Table 2: Sectoral Analysis of the Composition of Current Liabilities

\begin{tabular}{|l|l|l|l|}
\hline Sector & TCCL & STDCL & ACCCL \\
\hline Chemical \& oil & 0.6667 & 0.2067 & 0.1266 \\
\hline Consumer & 0.6596 & 0.2284 & 0.1120 \\
\hline Retail & 0.8055 & 0.0698 & 0.1246 \\
\hline Industrial & 0.6991 & 0.2190 & 0.0819 \\
\hline Construction & 0.7526 & 0.1180 & 0.1293 \\
\hline Mining & 0.5351 & 0.2459 & 02190 \\
\hline Technology & 0.8197 & 0.1217 & 0.0586 \\
\hline Leisure & 0.5046 & 0.2614 & 0.2343 \\
\hline
\end{tabular}

Source: Own calculations using a balanced panel over the period 2001 to 2010. Data obtained from the McGregor BFA library.

\subsection{Percentage composition of working capital finance}

Table 3 shows the financing composition of working capital investments; Trade Credit to Current Assets (TCCA), Short 
Term Debt to Current Assets (STDCA), Accruals to Current Assets (ACCA) and Long Term Funds to Current Assets (LTFCA). CLCA is a sum of TCCA, STDCA and ACCA and shows the extent to which firms used short term funds to finance current assets. Approximately three quarters of the current assets are funded by short term finance and the remainder is funded by long term funds.

The analysis shows that approximately half of the current assets were financed by trade credit. On average, short term debt and accruals respectively financed less than a fifth and a tenth of the current assets held by these firms. Supplier credit used to support current assets was at its lowest in 2009, suggesting that the global financial crisis had a negative impact on trade credit received by firms during the crisis.

The difference between Current Assets and Current Liabilities (Net Working Capital (NWC) represents a proportion of working capital investment financed by long term funds. On average these firms financed nearly a quarter of their current assets using long term funds. The period 2006 to 2010 witnessed increased usage of long term funds to finance current assets (an increase of 11 percentage points), which suggests that these firms followed a more conservative working capital financing policy, finance their current assets using more long term funds than short term funds.

The trend exhibited in Table 3 seems to suggest that these firms switched from trade credit to long term funds in financing current assets because the increasing use of long term funds is almost matched by the declining in the reliance on trade credit to finance current assets over the period 2006 - 2010. There was notable increase (5 percentage points) in the use of long term funds financing current assets between 2008 and 2009. In 2009 firms used more of long term funds to support their working capital investment which explains the challenges of accessing short term funds during crises times. Internal resources and access to external long term funds play a crucial role in supporting working capital investment during times of a credit crunch like the 2009 global financial crisis when access to funds was very limited.

Table 3: Percentage composition of working capital finance

\begin{tabular}{|l|l|l|l|l|l|}
\hline Year & TCCA & STDCA & ACCA & CLCA & LTFCA \\
\hline 2001 & 0.5092 & 0.1725 & 0.0780 & 0.7597 & 0.2403 \\
\hline $\mathbf{2 0 0 2}$ & 0.5180 & 0.1537 & 0.0872 & 0.7590 & 0.2410 \\
\hline $\mathbf{2 0 0 3}$ & 0.5187 & 0.1933 & 0.0882 & 0.8002 & 0.1998 \\
\hline $\mathbf{2 0 0 4}$ & 0.5160 & 0.1629 & 0.1018 & 0.7807 & 0.2193 \\
\hline $\mathbf{2 0 0 5}$ & 0.5061 & 0.1535 & 0.1101 & 0.7698 & 0.2302 \\
\hline $\mathbf{2 0 0 6}$ & 0.5144 & 0.1640 & 0.1160 & 0.7943 & 0.2057 \\
\hline $\mathbf{2 0 0 7}$ & 0.5024 & 0.1706 & 0.1070 & 0.7801 & 0.2199 \\
\hline $\mathbf{2 0 0 8}$ & 0.4929 & 0.1738 & 0.0934 & 0.7601 & 0.2399 \\
\hline $\mathbf{2 0 0 9}$ & 04755 & 0.1677 & 0.0647 & 07079 & 0.2921 \\
\hline $\mathbf{2 0 1 0}$ & 0.4852 & 0.1479 & 0.0611 & 0.6942 & 0.3058 \\
\hline overall & 0.5038 & 0.1660 & 0.0908 & 0.7606 & 0.2394 \\
\hline
\end{tabular}

Source: Own calculations using a balanced panel over the period 2001 to 2010. Data obtained from the McGregor BFA library

The literature review section discussed the concept of permanent and temporary working capital. Assuming that these firms pursue the matching principle where long term funds support permanent working capital and short-term funds support temporary working capital, it can be inferred that these firms' distribution of permanent and temporary working capital is approximately $25 \%$ and $75 \%$ respectively.

The cost of a financing instrument is one of the key determinants of its feasibility or otherwise and potentially plays an important role in its selection. When implicit costs are ignored (the cost of foregoing cash discount), trade credit is considered the least costly short-term financing instrument while short-term debt is the most expensive. On the basis of the cost of finance only, it becomes clear why trade credit finances much of the working capital. The average short term lending rate for the study period 2001-2010 was 13\%. The average ratio of short term bank debt to trade is $30 \%$ which means for every 1 rand of trade credit there is only 30cents of short term debt, a clear indication that short term debt lags far behind trade credit.

One evident outcome of the working capital financing trends is that these firms have wider sources of finance and seem to have the ability to switch from one source to another in line with macroeconomic fundamentals. While large firms have the wider sources of finance and can easily switch from one source to the other, SMEs are heavily constrained and 
have limited access to financial markets (Padachi, Howorth, \& Narasimhan, 2012).

\subsection{Sectoral Analysis of composition of working capital finance}

The composition of working capital finance among the sample sectors is given in Table 4. Among the eight sectors, the mining and construction sectors are the most aggressive sectors (as shown by the lowest contribution of long term funds of $13 \%$ and $19 \%$ respectively). The leisure sector is the most conservative in managing working capital (as shown by a positive LTFCA of 30\%), followed by the technology (33\%). All sectors financed at least $70 \%$ of their current assets were by short-term finance. Short term debt financed the least current assets (9\%) and the most current assets (25\%) in the technology sector and the mining sector respectively.

Table 4: Sectoral Analysis of the Composition of working capital finance

\begin{tabular}{|l|l|l|l|l|l|}
\hline Sector & TCCA & STDCA & ACCA & CLCA & LTFCA \\
\hline Chemical \& oil & 0.4656 & 0.1663 & 0.0911 & 0.7230 & 0.2770 \\
\hline Consumer & 0.4484 & 0.2046 & 0.0849 & 0.7379 & 0.2621 \\
\hline Retail & 0.6078 & 0.0498 & 0.0733 & 0.7309 & 0.2691 \\
\hline Industrial & 0.5154 & 0.1813 & 0.0577 & 0.7543 & 0.2457 \\
\hline Construction & 0.6256 & 0.1291 & 0.1160 & 0.8707 & 0.1293 \\
\hline Mining & 0.4058 & 0.2469 & 0.1616 & 0.8143 & 0.1857 \\
\hline Technology & 0.5791 & 0.0939 & 0.0378 & 0.7108 & 0.2892 \\
\hline Leisure & 0.3308 & 0.2207 & 0.1475 & 0.6990 & 0.3010 \\
\hline
\end{tabular}

Source: Own calculations using a balanced panel over the period 2001 to 2010. Data obtained from the McGregor BFA library.

\subsection{Distribution of Current Asset Values and Liquidity Rankings}

Working capital investment structure refers to the distribution of the working capital and shows which current asset constitutes the largest proportion of the working capital. The study examined the distribution of the working capital over the ten-year period to establish whether the level of investment in the four components exhibited any pattern or and whether there have been any structural changes. Results of the distribution in working capital investment are shown in Table 5. The average investment in working capital was distributed as follows; inventory 34\%, trade receivables 39\%, cash holdings $21 \%$ and other current assets $7 \%$. Inventory and trade receivables constitute nearly three quarters of the total working capital investment which clearly show that on average these firm the maintained much of their working capital stocks and receivables.

The proportion of inventory /stock to total current assets (STCA) does not follow a well-defined pattern but fluctuates between $33 \%$ (the lowest proportion in 2005) and $41 \%$ (the highest proportion in 2003). The proportion of trade debtors to current assets (TDCA) generally followed a downward trend over the ten-year period from the highest proportion of $43 \%$ recorded in 2001 to the lowest of 35\% in the years 2008 and 2009 . The downward trend in TDCA suggests that over the ten-year period these firms were probably moving from liberal to tight credit extension policies, or they intensified their collections or sold their goods more on cash than credit; hence the reduction in their investments in trade receivables. The proportion of cash and marketable securities to current assets (CMSCA) trended upwards from $18 \%$ in 2001, peaking at 23\% in 2006 and almost follow a downward trend in for the remainder of the study period. Other current assets (OTCA) averaged $6 \%$ in the first five years of the study and then follow trended upwards from 5\% in 2006 to $12 \%$ in 2010.

Investments in the different components of working capital impact on the liquidity of a company because these components have varying degrees of liquidity. An attempt was made to assess overall liquidity by using a comprehensive test based on the sum of scores (Liquidity ranks) of separate individual rankings under the four criteria; TDCA, CMSCA, SKCA and OTCA. The category of current assets that constitute the largest portion in total current assets will inevitably affect the short-term solvency position of the company in a significant way. Rankings were done in the following order; a high value of TDCA, CMSCA, and OTCA indicates greater liquidity while a high value of SKCA shows a less favourable position (because inventory is considered the least liquid current asset).

Table 5 shows the final liquidity rank for the ten years and the results show that the most favourable and least 
favourable years were 2005 and 2003 respectively. The liquidity ranking of 2005 is not surprising as this period has been rated as the best times the South African economy has enjoyed in the post-apartheid era. The liquidity ranking of 2003 can also be attributed to the performance of the economy during this period which was characterised by high inflation, high interest rates and a general slowdown in the economy as shown by the quarter on quarter growth in gross domestic product (GDP) figures in Appendix 2. Appendix 2 shows the growth in gross domestic product quarter on quarter between 2002 and 2003 was declining from the second quarter of 2002 to the second quarter of 2003. The economy recovered in the last two quarter of 2003. The prime lending rate reached a peak of 17\% (averaged $15.75 \%$ in 2002 and $15.3 \%$ in 2003) while the repo rate \% (averaged $12.25 \%$ in 2002 and $11.45 \%$ in 2003).

An interesting observation is how firms responded to the slowdown in the economy in the period $2002-2003$ and 2008 - 2009. Prior to the two recessions (2002-2003) and (2008-2009), firms were holding huge inventory investments, though the 2002-2003 figures were much higher than the 2008-2009 figures. Cutting down the most illiquid current asset, inventory is the major focus of firms during the recession. The proportion of inventory to total current assets was equal to the proportion receivables to total current assets in 2003 and 2004. Considering that inventory is not as liquid as receivables, it can be said that these figures represent an over investment in inventory during this period. Post 2004 the study observed that the proportion of inventory to current assets was 33\%, representing a 7 percentage points reduction which suggests that these firms used inventory reductions to improve their liquidity positions (Lamberson, 1995), consistent with the finding of Blinder and Maccini (1991) that recessions are associated with inventory cut downs. The 2008 and 2009 liquidity rankings can be attributed to the recent global economic crisis. Economic slowdown impact on the firms' ability to turn over their stock, grant/access credit, settle payables, collect receivables and access to short term finance. Periods of expansion in the economy have direct opposite effects on the company.

Table 5: Distribution of Current Asset Values and Liquidity Rankings

\begin{tabular}{|c|c|c|c|c|c|c|c|c|c|c|}
\hline & Distribution of Current Asset Values & \multicolumn{5}{c|}{ Liquidity Rankings } & & \\
\hline Year & SKCA & TDCA & CMSCA & OTCA & SKCALR & TDCALR & CMSCALR & OTCALR & Total Rank & Final Rank \\
\hline 2001 & 0.3282 & 0.4298 & 0.1838 & 0.0581 & 5 & 1 & 9 & 9 & 24 & 6 \\
\hline 2002 & 0.3279 & 0.4176 & 0.1837 & 0.0708 & 4 & 2 & 10 & 4 & 20 & 4 \\
\hline 2003 & 0.4053 & 0.4053 & 0.1970 & 0.0631 & 10 & 3 & 8 & 7 & 28 & 10 \\
\hline 2004 & 0.3981 & 0.3981 & 0.2193 & 0.0692 & 9 & 4 & 3 & 5 & 21 & 5 \\
\hline 2005 & 0.3251 & 0.3908 & 0.2203 & 0.0638 & 1 & 6 & 2 & 6 & 15 & 1 \\
\hline 2006 & 0.3266 & 0.3937 & 0.2282 & 0.0516 & 3 & 5 & 1 & 10 & 19 & 2 \\
\hline 2007 & 0.3316 & 0.3803 & 0.2165 & 0.0626 & 6 & 7 & 4 & 8 & 25 & 8 \\
\hline 2008 & 0.3373 & 0.3465 & 0.2021 & 0.0800 & 7 & 8 & 6 & 3 & 24 & 6 \\
\hline 2009 & 0.3412 & 0.3465 & 0.2154 & 0.0969 & 8 & 10 & 5 & 2 & 25 & 8 \\
\hline 2010 & 0.3258 & 0.3584 & 0.1989 & 0.1170 & 2 & 9 & 7 & 1 & 19 & 2 \\
\hline Overall & 0.3447 & 0.3910 & 0.2065 & 0.0733 & \multicolumn{7}{|c|}{} \\
\hline \multicolumn{8}{|c|}{ Kendall coefficient of concordance among four sets of liquidity ranks (W) is 0.1015 p-value 0.93} \\
\hline
\end{tabular}

Source: Own calculations using a balanced panel over the period 2001 to 2010. Data obtained from the McGregor BFA library.

Correia, Flynn, Uliana, and Wormald (2011) give examples of JSE-listed firms (Reunert, Barloworld, Omnia) which reduced their working capital investments by cutting down their inventory holdings and intensifying collections during the recent global economic crisis and this could be the main reason why 2010 has a good ranking in the ten year period. Post recessions periods (2005 and 2010) show that these firms have strong liquidity positions which suggests that during economic crisis, firms try to improve their current asset mix in particular, improving the liquidity position of the firm. This adds weight to the assertion that working capital management receives more attention during an economic crisis than when the economy is in expansion (Reason, 2008).

Cash holdings of the period 2005 - 2007 (a period characterised by low inflation levels and remarkable economic growth) were higher than the cash holdings of the period $2002-2003$ and 2008 - 2009 (periods characterised by slowdown in the economy, high inflation rates and high lending rates). Consequently, the liquidity rankings of cash holdings during expansion periods were more favourable than recession periods, which suggest that firms hold high levels of cash and marketable securities during good economic times, probably to take advantage of expansion 
opportunities. During recession periods holding cash is not worthwhile because of high negative real interest rates. The focus tends to be on improving liquidity position of the firm as access to external finance tends to be very limited.

The Kendall's coefficient of concordance (W) was computed to determine the degree of uniformity among the four sets of rankings. The computed value of $\mathrm{W}$ is 0.10 and is not statistically significant. It reveals that there is no close association among the liquidity of various components of working capital during the period of study.

\subsection{Sectoral Analysis of the Composition of Current assets and Liquidity rankings}

The highest ten-year averages were reported as follows; stock $39 \%$ in the retail sector, trade debtors $50 \%$ in the technology sector and the construction sector cash and marketable securities 29\% /other 37\% the mining sector has the highest other current assets $11 \%$. The lowest ten-year averages were reported as follows; stock $27 \%$ in the technology sector, trade debtors $33 \%$ in the mining sector and the retail sector the industrial goods and services sector has the lowest cash and marketable securities $16 \%$, the chemical and oil sector has the other current assets a paltry $2.41 \%$.

Table 6: Sectoral Analysis of the Composition of Current assets

\begin{tabular}{|c|c|c|c|c|c|c|c|c|c|c|}
\hline Sector & SKCA & LR & TDCA & LR & CMSCA & LR & ODCA & LR & Total Rank & Final Rank \\
\hline Chemical \& oil & 0.3831 & 7 & 0.4383 & 3 & 0.1758 & 7 & 0.0241 & 7 & 24 & 7 \\
\hline Consumer & 0.3451 & 4 & 0.3613 & 6 & 0.1985 & 5 & 0.0991 & 2 & 10 & 5 \\
\hline Retail & 0.3939 & 8 & 0.3272 & 7 & 0.1967 & 6 & 0.0703 & 4 & 25 & 8 \\
\hline Industrial & 0.3632 & 6 & 0.4453 & 2 & 0.1506 & 8 & 0.0654 & 5 & 21 & 6 \\
\hline Construction & 0.2758 & 3 & 0.4255 & 4 & 0.2928 & 2 & 0.0585 & 6 & 15 & 3 \\
\hline Mining & 0.3507 & 5 & 0.3254 & 8 & 0.2099 & 4 & 0.1139 & 1 & 18 & 4 \\
\hline Technology & 0.2747 & 2 & 0.5003 & 1 & 0.2647 & 3 & 0.0074 & 8 & 14 & 2 \\
\hline Leisure \& recreation & 0.2304 & 1 & 0.3628 & 5 & 0.3666 & 1 & 0.0707 & 3 & 10 & 1 \\
\hline
\end{tabular}

Source: Own calculations using a balanced panel over the period 2001 to 2010. Data obtained from the McGregor BFA library.

Table 6 also shows that the most liquid sectors were the leisure and recreation sector and the technology sector largely due to high levels of cash holdings and low investment levels of inventory, the most illiquid current asset. Consistent with expectation, the most illiquid sectors are retail, chemical and oil and the industrial sectors because they have the highest proportion of inventory

\section{Conclusion}

Using a sample of 92 JSE-listed firms, operating in eight different sectors for the period 2001 - 2010, the study found that trade credit is the dominant financing short-term instrument and plays an important role in financing working capital investments. Short-term debt to plays complementary role and contributing about a fifth to short-term finance and financing about a fifth of the working capital investments over the study period for the sample firms. Overall the study found that these firms have wider sources of finance and are able to switch from one source to another.

The global financial crisis had an impact on both the working capital financing and investment management of the sample firms. The results show that firms in different economic sectors use different approaches to manage their current assets, some sectors are aggressive and others are conservative in managing their working capital. Firms in this study appeared to align their working capital investment and financing strategies in line with the macroeconomic fundamentals like inflation and interest rates. The results obtained suggest that the performance of the economy impact on the firms' inventory, payables and receivables management and other various components working capital. This conclusion is still tentative however; and will be investigated more deeply in the building of an econometric model of firms financing and investment strategies in the next stage of this research.

\section{References}

Bhattacharya, H. (2009). Working Capital Management Strategies And Techniques (2nd ed.). New Dehli: PHI Learning Pvt. Ltd. Blinder, A. S., \& Maccini, L. J. (1991). The resurgence of inventory research: what have we learned? Journal of Economic Surveys, 5(4), 
291-328.

Brealey, R. A., Myers, S. C., \& Allen, F. (2008). Principles of Corporate Finance (9th International Edition ed.). New York: McGraw Hill/Irwin.

Chiou, J.-R., Cheng, L., \& Wu, H.-W. (2006). The determinants of working capital management. Journal of American Academy of Business, 10(1), 149-155.

Correia, C., Flynn, D., Uliana, E., \& Wormald, M. (2011). Financial managment (7th ed.). Cape Town: Juta

Ernst., \& Young. (2010). All tied-up Working capital management report -2010. http://www.ey.com/Publication/vwLUAssets/All-tiedup_2010/\$FILE/All-tied-up_2010.pdf

Firer, C., Ross, S. A., Westerfield, R. W., \& Jordan, B. D. (2012). Fundamentals of Corporate Finance (5th South African ed.). Berkshire McGra-Hill Education

Gitman, L. J., Beaumont Smith, M., Hall, J., Lowies, B., Marx, J., Strydom, B., \& van der Merwe, A. (2010). Principles of Managerial Finance : Global and South African Perspectives (1st edition ed.). Cape Town: Pearson Education South Africa

Lamberson, M. (1995). Changes in working capital of small firms in relation to changes in economic activity. American Journal of Business, 10(2), 45-50.

Maksimovic, V., \& Demirgüç-Kunt, A. (2001). Firms as Financial Intermediaries: Evidence from Trade Credit Data. World Bank Policy Research Working Paper(2696).

Myers, S. C. (1984). The capital structure puzzle. The Journal of finance, 39(3), 574-592.

Padachi, K. (2006). Trends in Working Capital Management and its Impact on Firms' Performance: An Analysis of Mauritian Small Manufacturing Firms. . International Review of Business Research Papers, 2, 45-58.

Padachi, K., Howorth, C., \& Narasimhan, M. S. (2012). Working Capital Financing Preferences: The Case Of Mauritian Manufacturing Small And Medium-Sized Enterprises (SMEs). Asian Academy of Management Journal of Accounting and Finance, 8(1), 125127.

Petersen, M. A., \& Rajan, R. G. (1997). Trade credit: theories and evidence. Review of Financial Studies, 10(3), 661-691.

Reason, T. (2008). Preparing your company for reccession. CFO Magazine. www.cfo.com/article/cfm/10600055

REL. (2009). The Working Capital Survey REL / CFO Magazine 2009.

Salawu, R. O. (2007). Capital Industry Practice And Aggressive Conservative Working Capital Policies In Nigeria. . Global Journal of Business Research, 1(2), 109-117.

Sathyamoorthi, C. R., \& Wally-Dima, L. B. (2008). Working Capital Management: The Case of Listed Retail Domestic Companies in Botswana,. The Icfaian Journal of Management Research, 6(5), 7-24.

Siddiquee, M. M., \& Khan, S. M. D. (2009). Analyzing Working Capital Performance: Evidence from Dhaka Stock Exchange Ltd (DSE)Ltd. . http://ssrn.com/abstract=1374210

Skerritt, P. (2009). The Financial Landscape. . In Z. B. C. Van Zyl, P. Skerritt \& I. Goodspeed (Ed.), Understanding the South African Financial Markets (3rd ed.). Pretoria:: Van Schaik Publishers.

Van Horne, J. C. (2002). Financial Management and Policy (12th ed.). New Jersey Prentice Hall.

Zapalska, A., Clark, R., \& Shao, L. (2004). Funding working capital requirements in emerging markets perspective. . Investment management and financial innovations, 1, 88-99

\section{Appendix 1}

\section{Lending and Treasury Bills rates}

\begin{tabular}{|c|c|c|c|c|c|c|c|c|c|c|}
\hline Year & 2001 & 2002 & 2003 & 2004 & 2005 & 2006 & 2007 & 2008 & 2009 & 2010 \\
\hline Prime rate & 13.77 & 15.75 & 14.96 & 11.29 & 10.63 & 11.17 & 13.17 & 15.13 & 11.71 & 9.83 \\
\hline Repo rate & 10.92 & 12.25 & 11.46 & 7.79 & 7.125 & 7.67 & 9.67 & 11.63 & 8.21 & 6.33 \\
\hline 10 year yield & 11.63 & 10.44 & 9.15 & 8.38 & 7.57 & 7.81 & 8.29 & 7.82 & 9.03 & 8.38 \\
\hline 91 day yield & 9.66 & 11.19 & 10.63 & 7.54 & 6.89 & 7.37 & 9.13 & 10.8 & 7.84 & 6.46 \\
\hline
\end{tabular}

Source: South African Reserve Bank

\section{Appendix 2}

Table 4A: Growth in gross domestic product quarter on quarter

\begin{tabular}{|c|c|c|c|c|}
\hline Year & Quarter1 & Quarter 2 & Quarter 3 & Quarter 4 \\
\hline 2002 & 4.4 & 5.2 & 4.6 & 3.4 \\
\hline 2003 & 2.6 & 2.0 & 2.2 & 2.3 \\
\hline 2004 & 2.6 & 5.7 & 6.7 & 4.3 \\
\hline 2005 & 4.1 & 7.4 & 5.6 & 2.7 \\
\hline
\end{tabular}




\begin{tabular}{|c|c|c|c|c|}
\hline 2006 & 6.2 & 6.7 & 5.8 & 6.4 \\
\hline 2007 & 6.1 & 3.4 & 5.1 & 5.7 \\
\hline 2008 & 2.5 & 5.5 & 1.3 & -0.7 \\
\hline 2009 & -7.4 & -2.8 & 0.9 & 3.2 \\
\hline
\end{tabular}

Source: StatsSA 